\title{
Reciprocal regulation of activin A and inhibin B by interleukin-1 (IL-1) and follicle-stimulating hormone (FSH) in rat Sertoli cells in vitro
}

\author{
Y Okuma, K Saito, A E O'Connor, D J Phillips, D M de Kretser \\ and $\mathbf{M} \mathbf{P}$ Hedger
}

Monash Institute of Reproduction and Development, Monash University, Melbourne, Victoria, Australia

(Requests for offprints should be addressed to M Hedger; Email: Mark.Hedger@med.monash.edu.au)

\begin{abstract}
In several biological systems, the inhibin $\beta_{\mathrm{A}}$ homodimer activin $\mathrm{A}$ is stimulated by, and in turn, inhibits the action of interleukin (IL)-1 (both IL-1 $\alpha$ and IL-1 $\beta$ ) and IL-6. The possibility that a similar regulatory relationship operates within the testis was investigated. Sertoli cells from immature (20-day-old) rats were cultured with human IL-1 $\alpha$ or IL-1 $\beta$, human IL-6 and/or ovine FSH or dibutyryl cAMP. Activin A and the inhibin dimers, inhibin $\mathrm{A}$ and inhibin $\mathrm{B}$, were measured by specific ELISA. Immunoreactive inhibin (ir-inhibin) was measured by RIA. Activin/inhibin subunit mRNA expression was measured by quantitative real-time PCR. Both IL-1 isoforms, but not IL-6, stimulated activin A secretion through increased synthesis of $\beta_{\mathrm{A}^{-}}$-subunit mRNA. IL-1 also stimulated activin $A$ secretion by testicular peritubular cells. In contrast to the effect on activin A, IL-1 suppressed
\end{abstract}

inhibin $\beta_{\mathrm{B}}$-subunit and, to a lesser extent, $\alpha$-subunit mRNA expression, thereby reducing basal and FSHstimulated inhibin B secretion by the Sertoli cells. Conversely, FSH inhibited basal activin A secretion and antagonised the stimulatory effects of IL-1. Dibutyryl cAMP partially inhibited the action of IL-1 on activin A secretion, but had no significant effect on basal activin A secretion. Secretion of inhibin A was low in all treatment groups. These data demonstrate that IL-1 and FSH/cAMP exert a reciprocal regulation of activin $\mathrm{A}$ and inhibin $\mathrm{B}$ synthesis and release by the Sertoli cell, and suggest a role for activin A as a potential feedback regulator of IL-1 and IL-6 activity in the testis during normal spermatogenesis and in inflammation.

Journal of Endocrinology (2005) 185, 99-110

\section{Introduction}

Testicular function is regulated by the pituitary gonadotrophins, follicle-stimulating hormone (FSH) and luteinising hormone ( $\mathrm{LH})$, androgens and a complex network of paracrine interactions. Considerable evidence indicates that testicular paracrine regulation involves the inflammatory cytokines, interleukin-1 (IL-1) and IL-6 (Jégou et al. 1995), and activin, a member of the transforming growth factor- $\beta$ (TGF $\beta$ ) family of cytokines with a broad range of immunoregulatory actions (Phillips et al. 2001, de Kretser et al. 2004).

Typically, IL-1 and IL-6 are produced by activated monocytes and macrophages during inflammatory responses (Dinarello 1996). IL-1 exhibits two isoforms, IL- $1 \alpha$ and IL-1 $\beta$, which are only $30 \%$ identical at the peptide level, but bind to a common receptor to exert an almost identical range of biological actions, including the stimulation of IL-6 production (Dinarello 1996). In the normal testis, IL- $1 \alpha$ is produced by the Sertoli cells
(Gérard et al. 1991) and is regulated by the spermatogenic cycle (Söder et al. 1991). Expression of IL-1 $\alpha$ in cultured Sertoli cells is stimulated by phagocytosis of residual bodies, and by lipopolysaccharide (LPS), a bacterial inflammatory stimulus (Gérard et al. 1992). As in monocytes, IL-1 $\alpha$ stimulates IL-6 production by the Sertoli cell (Syed et al. 1995). IL-1 $\beta$ is not significantly expressed in the normal testis, but LPS upregulates expression of IL-1 $\beta$ and IL-1 $\alpha$ in Leydig cells (Cudicini et al. 1997) and in testicular interstitial macrophages (Hales et al. 1992, Jonsson et al. 2001).

Sertoli cells are regulated by FSH acting through a cAMP/protein kinase A-mediated pathway, and by androgens (Means et al. 1974). In vitro studies have confirmed that both IL-1 and IL-6 also have complex effects on Sertoli cell and spermatogenic cell function. IL-1 inhibits FSH-induced aromatase activity (Khan \& Nieschlag 1991), and stimulates production of lactate and transferrin in Sertoli cells (Hoeben et al. 1997, Nehar et al. 1998, Huleihel et al. 2002), the proliferation of developing 
rat Sertoli cells in culture (Petersen et al. 2002), and spermatogonial and preleptotene spermatocyte DNA synthesis in cultured tubules from adult rats (Parvinen et al. 1991). Although IL-6 also stimulates transferrin production by Sertoli cells (Boockfor \& Schwarz 1991), this cytokine inhibits meiotic DNA synthesis in preleptotene spermatocytes (Hakovirta et al. 1995).

Activins are dimers of two homologous protein subunits, $\beta_{\mathrm{A}}$ or $\beta_{\mathrm{B}}$; homodimers of the subunits are called activin $\mathrm{A}\left(\beta_{\mathrm{A}} \beta_{\mathrm{A}}\right)$ and activin $\mathrm{B}\left(\beta_{\mathrm{B}} \beta_{\mathrm{B}}\right)$ (Groome et al. 2001). Heterodimers of a distinct $\alpha$-subunit with one of the two $\beta$-subunits produce either inhibin $A\left(\alpha \beta_{A}\right)$ or inhibin $B\left(\alpha \beta_{B}\right)$. Activin A is produced by Sertoli cells, peritubular cells and Leydig cells from immature testes (Lee et al. 1989, de Winter et al. 1993, 1994), and Sertoli cells appear to produce some activin B (de Winter et al. 1993). The Sertoli cells are also the principal source of inhibin $\mathrm{B}$, which is the predominant inhibin isoform in the male (Illingworth et al. 1996). Inhibin B production by Sertoli cells is controlled by FSH, primarily through stimulation of the $\alpha$-subunit (Toebosch et al. 1988, Klaij et al. 1992), but there are very few data concerning specific regulation of the $\beta$-subunits or the formation of activin in the testis. While inhibin acts as circulating inhibitor of pituitary FSH secretion, the activins possess predominantly paracrine functions, and exert both stimulatory and inhibitory effects on spermatogonial cell proliferation in vitro, and inhibitory effects on Sertoli cell proliferation (Mather et al. 1990, Hakovirta et al. 1993, Boitani et al. 1995, Meehan et al. 2000).

As a consequence of their actions on Sertoli and germ cell activity in vitro, it has been suggested that IL-1, IL-6 and activin may play a role in the fine regulation of spermatogenesis. Consequently, interaction between these cytokines is also likely to be important, and there is evidence for such an interaction between IL-1/IL-6 and activin in several tissues. For example, IL-1 stimulates activin $\beta_{\mathrm{B}}$ mRNA accumulation, as well as the mRNA for its binding protein, follistatin, in the pituitary, thereby regulating FSH secretion (Bilezikjian et al. 1998). Activin $\mathrm{A}$ is upregulated in monocytes during inflammation (Shao et al. 1992) and inhibits proinflammatory and immunoregulatory activities of both IL-1 and IL-6 (Yu et al. 1998, Phillips et al. 2001). IL-1 potentiates the inhibitory effect of activin on liver cell proliferation, and stimulates activin A production in cultures of bone marrow stromal cells, synoviocytes, chondrocytes and placental cells (Shao et al. 1992, Keelan et al. 1998, Yu et al. 1998, Russell et al. 1999, Abe et al. 2001).

A similar pattern of interactions might be expected to operate in the testis. In the present study, we investigated regulation of activin and inhibin by IL- 1 and IL- 6 in the rat Sertoli cell in vitro, and their interaction with FSH and cAMP, using a two-site enzyme-linked immunosorbant assay (ELISA), which can discriminate between the activin A, inhibin A and inhibin B dimers (Groome et al. 1994,
1996, Knight et al. 1996). Interactions between IL-1/IL-6 and activin/inhibin would have important implications both for normal regulation of spermatogenesis and for the progression of spermatogenic disruption during inflammation (O'Bryan et al. 2000).

A better understanding of this overlap between the regulation of testicular function and immune processes may help to explain the causes of male infertility commonly associated with illness, infection and inflammation.

\section{Materials and Methods}

\section{Isolation and culture of Sertoli cells}

Sertoli cells were prepared from immature (20-day-old) male Sprague-Dawley rats (Central Animal House, Monash University, Victoria, Australia) as previously described (Risbridger et al. 1989), with minor modifications. Briefly, testes were decapsulated, and the seminiferous tubules were partially drawn apart with forceps, before dissociation in Dulbecco's modified Eagle's medium plus Ham's nutrient mixture F-12 (DMEM:F12; Gibco, Grand Island, NY, USA) through the following series of enzyme digestions in a shaking water-bath $(90$ cycles $/ \mathrm{min}$, $37^{\circ} \mathrm{C}$ ): 1. collagenase (type II, $300 \mathrm{U} / \mathrm{ml}$; Worthington Biochemical, Lakewood, NJ, USA) and DNase (type I, $5 \mu \mathrm{g} / \mathrm{ml}$; Sigma), $10 \mathrm{~min} ; 2$. collagenase, DNase and hyaluronidase (type II, $0.5 \mathrm{mg} / \mathrm{ml}$; Sigma), $20 \mathrm{~min}$; 3. collagenase, DNase and hyaluronidase, $10 \mathrm{~min}$. The resulting cell preparation was resuspended in DMEM containing $0 \cdot 1 \%$ bovine serum albumin (BSA) (Sigma), penicillin $(5000 \mathrm{U} / \mathrm{ml})$ and streptomycin $(5000 \mu \mathrm{g} / \mathrm{ml})$ to a final concentration of approximately $1.0 \times 10^{6}$ cells $/ \mathrm{ml}$, and $1.0 \mathrm{ml}$ aliquots were transferred to Falcon 24-well culture plates (Becton-Dickinson Labware, Bedford, MA, USA). In some experiments the plates were precoated with $1.0 \mu \mathrm{g} / \mathrm{cm}^{2}$ mouse laminin (Becton-Dickinson) prior to the addition of the cell suspension. Laminin has been shown to influence Sertoli cell attachment, morphology and hormonal responses in vitro (Dym et al. 1991). The plated cells were incubated for $24 \mathrm{~h}$ at either $37^{\circ} \mathrm{C}$ or $32{ }^{\circ} \mathrm{C}$ in $5 \% \mathrm{CO}_{2} /$ air $(\mathrm{pH} 7 \cdot 2-7 \cdot 3$ ), after which time the medium containing unattached cells was removed. In some experiments, the attached cell layer was subjected to a brief hypotonic shock with water to lyse residual germ cells, the medium was replaced and the attached cells were allowed to recover for an additional $24 \mathrm{~h}$. After the washing step to remove unattached cells, fresh medium containing appropriate test substances was added to quadruplicate wells: human recombinant (hr)IL-1 $\alpha$ $(160000 \mathrm{U} / \mu \mathrm{g}), \mathrm{hrIL}-1 \beta \quad(200000 \mathrm{U} / \mu \mathrm{g}) \quad(\mathrm{R}$ and $\mathrm{D}$ Systems, Minneapolis, MN, USA), hrIL-6 (PeproTech, Rocky Hill, NJ, USA), dibutyryl cAMP (dbcAMP; Sigma), testosterone (Sigma) and ovine FSH (NIH oFSH20, $4453 \mathrm{IU} / \mathrm{mg}$; NIDDK, Bethesda, MD, USA). Medium was collected and replaced thereafter at 48-h 
intervals (days 3, 5 and 7 of culture). In some experiments, after removal of the medium, the attached cells were resuspended in $1 \mathrm{ml} 0 \cdot 01 \mathrm{M}$ PBS, $0 \cdot 1 \%$ Triton X-100 $(\mathrm{v} / \mathrm{v})$ and $0 \cdot 1 \% \mathrm{BSA}$, and homogenised in the culture wells. The cell lysates were centrifuged (10 $000 \boldsymbol{g}, 10 \mathrm{~min})$ to remove particulates, and the resulting supernatants collected. Media and cell lysates were stored at $-20{ }^{\circ} \mathrm{C}$ prior to ELISA. For studies on mRNA expression, total RNA was extracted from the Sertoli cells with Trizol reagent (Life Technologies, Rockville, MD, USA). All experiments were repeated at least twice.

\section{Alkaline phosphatase histochemistry}

Alkaline phosphatase histochemistry was performed on cultured cells at the end of the culture period by an established protocol (Chapin et al. 1987). In four sequential experiments, $8 \cdot 8 \pm 5 \cdot 0 \%$ (mean \pm s.D.) of the cultured cells were alkaline phosphatase-positive peritubular cells at day 3 of culture.

\section{Percoll gradient separation and assessment}

In some experiments, Sertoli cells and peritubular cells were separated on discontinuous Percoll (Pharmacia, Uppsala, Sweden) density gradients by a modification of the method described previously (Simpson et al. 1992). After enzymatic dispersal, the cell suspension was diluted in DMEM:F12 and applied to a $50 \mathrm{ml}$ discontinuous Percoll step gradient $(1.025$ to $1.075 \mathrm{~g} / \mathrm{ml})$ at $1158 \boldsymbol{g}$ for 20 min at $4{ }^{\circ} \mathrm{C}$. Sertoli cells were collected from a band between 1.045 and $1.055 \mathrm{~g} / \mathrm{ml}$, and peritubular cells were isolated between 1.06 and $1.07 \mathrm{~g} / \mathrm{ml}$ (purity of both fractions was $>98 \%$, based on alkaline phosphatase staining). Each fraction was washed three times in culture medium, diluted to approximately $1 \cdot 010^{6} \mathrm{cells} / \mathrm{ml}$, and plated as described above.

\section{Measurement of DNA content}

The attached Sertoli cells were washed with PBS, before $10 \%$ trichloroacetic acid was added to each well for $10 \mathrm{~min}$. The plates were then centrifuged at $100 \mathrm{~g}$ $\left(10 \mathrm{~min}, 4^{\circ} \mathrm{C}\right)$, and the supernatant was discarded. The PBS wash, acid treatment and centrifugation were repeated once more, before $0.5 \mathrm{ml}$ ice-cold ethanol was added to each well for $10 \mathrm{~min}$. Plates were centrifuged at $100 \mathrm{~g}\left(10 \mathrm{~min}, 4^{\circ} \mathrm{C}\right)$, and the supernatant was discarded. A $200 \mu \mathrm{l}$ aliquot of $0.3 \mathrm{M} \mathrm{NaOH}$ was added to each well, and the plate was agitated for $10 \mathrm{~min}$. Each well was neutralised by addition of $200 \mu \mathrm{l} 0.3 \mathrm{M} \mathrm{HCl}$ before samples were read in a spectrophotometer at $260-280 \mathrm{~nm}$.

\section{Inhibin radioimmunoassay (RIA)}

Immunoreactive inhibin (ir-inhibin) was measured in Sertoli cell culture media by heterologous, double- antibody RIA, using a rabbit antiserum (no. 1989) raised against bovine $31 \mathrm{kDa}$ inhibin, with iodinated bovine $31 \mathrm{kDa}$ inhibin as tracer, and an ovarian extract from PMSG-stimulated rats (ROVEA-88) as standard (Robertson et al. 1988). This assay, which is directed against the inhibin $\alpha$-subunit, detects the native inhibin dimer, but cross-reacts with several other proteins derived from the inhibin $\alpha$-subunit precursor (Groome et al. 2001). The assay limit of detection was $0 \cdot 2 \mathrm{ng} / \mathrm{ml}$. The intra-assay variation was $4 \cdot 6-9 \cdot 9 \%$, while the interassay coefficient of variation was $7 \cdot 0 \%(n=12$ assays).

\section{Activin A ELISA}

Activin A was measured by specific ELISA (Knight et al. 1996) according to the manufacturer's instructions (Oxford Bio-Innovations, Upper Heyford, Oxfordshire, UK) with some modifications. The standard used was human recombinant activin A, as described previously (Robertson et al. 1992). Standards and samples were diluted in unconditioned culture medium containing the same additives as were used in the culture. A $6 \%$ sodium dodecyl sulphate solution in PBS was added (3\% final concentration) followed by boiling for $3 \mathrm{~min}$. The samples were allowed to cool before the addition of $\mathrm{H}_{2} \mathrm{O}_{2}(2 \%$ final concentration) and subsequent 30-min incubation. Duplicates were added to the E4 (anti- $\beta_{\mathrm{A}}$ subunit) monoclonal antibody-coated plates and incubated overnight at room temperature. The plates were washed, and the second detection antibody (biotinylated-E4) was added for $2 \mathrm{~h}$ at room temperature. After washing, alkaline phosphatase linked to streptavidin was added to the wells and incubated at room temperature for $1 \mathrm{~h}$. After further washes, the alkaline phosphatase activity was detected with an amplification kit (ELISA Amplification System; Invitrogen, Carlsbad, CA, USA), whereby the substrate was incubated for $1 \mathrm{~h}$ at room temperature.

\section{Inhibin $A$ and $B$ ELISA}

Inhibin A and inhibin B were measured by specific ELISA (Groome et al. 1994, 1996) according to the manufacturer's instructions (Oxford Bio-Innovations) with some modifications. The standards used were an inhibin A standard provided with the kit, which had been calibrated against recombinant $32 \mathrm{kDa}$ inhibin and WHO 96/784 inhibin B reference standard (NIBSC, Potter's Bar, UK). Standards and samples were diluted in unconditioned culture medium and treated according to the manufacturer's protocol. Duplicates were added to the plates and incubated overnight at room temperature. The plates were washed, and the second detection antibody ( $\mathrm{R} 1$ coupled to alkaline phosphatase) was added for $3 \mathrm{~h}$ at room temperature. After washing, the alkaline phosphatase activity was 
Table 1 Oligonucleotide primer sequences, primer-specific LightCycler conditions and expected product sizes for rat inhibin family subunits and $\beta$-actin

\begin{tabular}{|c|c|c|c|c|}
\hline & Nucleotide sequence & $\begin{array}{l}\text { Annealing } \\
\text { temperature }\left({ }^{\circ} \mathrm{C}\right)\end{array}$ & $\begin{array}{l}\mathbf{M g} \\
(\mathrm{mM})\end{array}$ & $\begin{array}{l}\text { Product } \\
\text { size }(b p)\end{array}$ \\
\hline $\begin{array}{l}\text { Primer set } \\
\alpha \text {-Subunit }\end{array}$ & $\begin{array}{l}\text { 5'-GCCTTGGTCTCCTGCA-3' } \\
\text { 5'-ACGCGTAGGGACCTCATGCTCC-3' }\end{array}$ & 62 & 4 & 300 \\
\hline$\beta_{\mathrm{A}}$-Subunit & $\begin{array}{l}\text { 5'-TGGAGTGTGATGGCAAGGTC-3' } \\
5^{\prime} \text {-AGCCACACTCCTCCACAATC-3' }\end{array}$ & 60 & 3 & 339 \\
\hline$\beta_{\mathrm{B}}$-Subunit & $\begin{array}{l}\text { 5'-TCTTCATCGACTITCGGCTCAT-3' } \\
\text { 5'-TGTCAGGCGCAGCCACACTCCT-3' }^{\prime}\end{array}$ & 60 & 3 & 302 \\
\hline$\beta$-Actin & $\begin{array}{l}\text { 5'-GATATCGCTGCGCTCGTC-3' } \\
\text { 5'-TGGGGTACTTCAGGGTCAGG-3' }\end{array}$ & 60 & 3 & 202 \\
\hline
\end{tabular}

detected using an amplification kit (ELISA Amplification System; Invitrogen).

\section{$m R N A$ extraction and real-time PCR analysis}

Total RNA from Sertoli cell cultures was purified by the guanidinium thiocyanate-phenol-chloroform method of Chomczynski and Sacchi (1987). To remove genomic DNA contamination, samples were then treated with $2 \mathrm{U}$ of DNase I (Ambion, Austin, TX, USA) at $37^{\circ} \mathrm{C}$ for $60 \mathrm{~min}$, and the reaction was stopped by adding DNase inactivating reagent. Samples were then assessed by A260/ A280 spectrophotometry. One microgram of RNA for each sample was transcribed, using Superscript II and oligo dT13-15 (Gibco-BRL/Invitrogen). For every sample, a no-RT control also was performed, to verify the absence of contaminating genomic DNA in the PCR. mRNA expression was quantified by the Roche LightCycler (Roche, Mannheim, Germany), as previously described (Drummond et al. 2000). For PCR, $2 \mu \mathrm{l}$ of each cDNA preparation were diluted to a final concentration of 1:50 and added to individual capillary tubes with $\mathrm{dNTP}, \mathrm{Mg}^{2+}$, SYBR Green and relevant primers. Magnesium concentrations, annealing temperatures, extension times and primer-specific nucleotide locations and sequences are shown in Table 1. Forty cycles of PCR were programmed to ensure that the log-linear phase was reached. At the completion of the reaction, melting curve analysis was performed to establish the specificity of the DNA products produced. PCR products were removed from the capillary tubes and visualised by gel electrophoresis to confirm the product size and integrity of the PCR reaction. In every instance, samples from an individual culture experiment were analysed for each primer set in a single PCR run. The intra-assay variation was $4 \%$ for each primer set. The log-linear portion of the PCR amplification curve was identified with the threshold or crossing point (represented in cycle number) defined as the intersection of the best-fit line through the log-linear region and the noise band. In these studies, a normal rat cDNA preparation was employed as a quality control and used in all reactions to ensure cycling conditions remained constant between experimental runs. The levels of expression of each mRNA and their estimated crossing points in each sample were determined with the LightCycler software, and the activin/inhibin subunit mRNAs were normalised against $\beta$-actin. These data were used to calculate a relative activity value, determined as the ratio of IL-1-stimulated mRNA to basal mRNA expression at each culture time point.

\section{Statistical analysis}

All data were analysed by one-way or two-way analysis of variance (ANOVA) following appropriate transformation to normalise data and equalise variance, where necessary. Mean values were compared by either the StudentNewman-Keuls multiple range test or Dunnett's test for multiple comparisons with a control (Sigmastat Version 1.0; Jandel Scientific Software, San Rafael, CA, USA). Differences between responses were considered statistically significant at the $P<0.05$ level. ELISA dose-response curves were compared by linear regression after log-log transformation of the data. The curves were considered to be parallel if the 95\% confidence limits of the slopes overlapped.

\section{Results}

\section{Assay validation for medium samples}

In order to measure activin A in the study, it was necessary to validate the assays for tissue culture medium. Initial dose-response studies in standards and samples diluted in culture medium showed a non-linear response in samples and a decrease in sensitivity in the assay compared with assays using a buffer-based standard. Investigations revealed that culture media, in particular carbonate-based media such as DMEM, increased in $\mathrm{pH}$ to varying degrees after storage/freezing. The change in the $\mathrm{pH}$ had the effect of decreasing the amount of activin A binding to the 


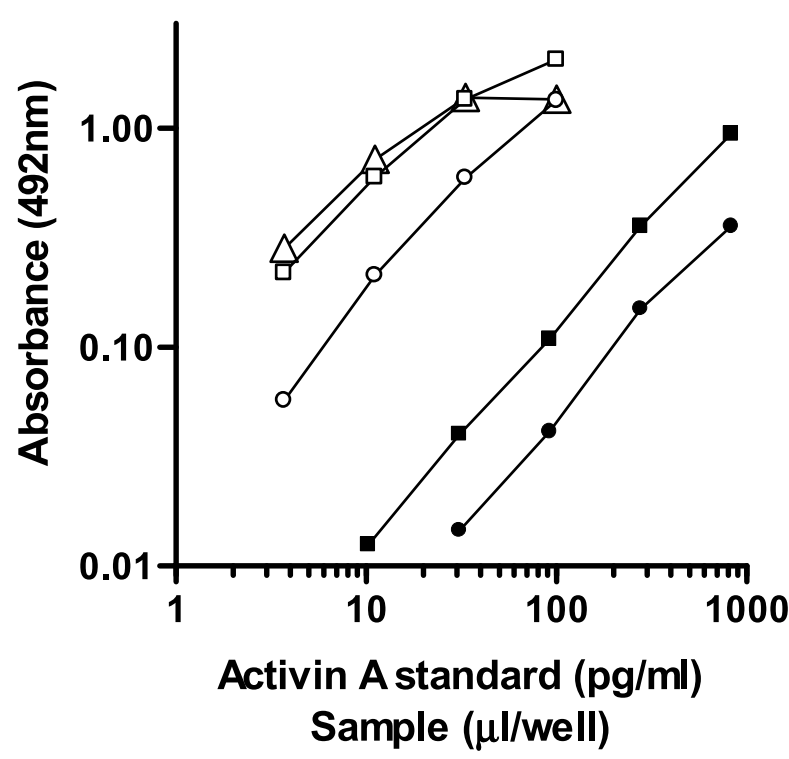

Figure 1 Log-log transformed dose-response curves of activin A standard (filled symbols) and Sertoli cell culture media samples (open symbols) in the activin A ELISA. The dilution of the samples added to the wells is also indicated. Standards and samples were diluted in culture medium (DMEM/0.1\% BSA) with different pretreatments: addition of $6 \% \mathrm{SDS} / \mathrm{H}_{2} \mathrm{O}(\bigcirc)$, addition of $6 \%$ SDS/0.05 M PBS ( $\square$ ) and addition of $6 \%$ SDS/ $\mathrm{H}_{2} \mathrm{O}$ after dilution in fresh, buffered medium $(\triangle)$. All values are mean of duplicates.

antibodies and therefore resulted in underestimation of the amount of activin $\mathrm{A}$ in the samples and decrease in the sensitivity of the assay (Fig. 1). In the published method (Knight et al. 1996), there was no addition of buffer in the activin A ELISA sample treatment, unlike the methods for the inhibin A and B ELISAs. However, when 0.05 M PBS was added to the sample treatment in the form of $6 \%$ SDS/0.05 M PBS, instead of the usual 6\% SDS solution in water, a uniform $\mathrm{pH}$ of all culture medium samples and diluent resulted, regardless of storage. Serial dilution of samples treated in this manner gave dose-dependent responses that were parallel to the standard (Fig. 1). There was also an increase in the signal, resulting in an approximately threefold increase in the sensitivity of the assay. The assay limit of detection was $10 \mathrm{pg} / \mathrm{ml}$. Recoveries of culture medium 'spiked' with activin A were 104.5 $\pm 6 \cdot 7$ (mean \pm S.D.; $n=3$ experiments). Intra-and inter-plate percentage coefficients of variation were $7 \cdot 4 \%$ and $6 \cdot 3 \%$ respectively ( $n=12$ assays).

Serial dilutions of samples from Sertoli cell culture medium gave dose-dependent responses which were parallel to the respective standard, also diluted in culture medium, in both the inhibin A and inhibin B ELISAs (data not shown). The detection limits for inhibin A and inhibin B were 2 and $10 \mathrm{pg} / \mathrm{ml}$ respectively. Recoveries of culture medium 'spiked' with inhibin A were $101 \cdot 9 \pm 7 \cdot 8 \%$ (mean \pm S.D.; $n=3$ experiments); recoveries of spiked inhibin B were $105 \cdot 6 \pm 4 \cdot 1 \%(n=5$ experiments). All samples were assayed in a single plate for inhibin A and a single plate for inhibin B, with intraplate percentage coefficients of variation of $4 \cdot 2 \%$ and $2 \cdot 2 \%$ respectively.

Effects of IL-1 and IL-6 on activin A production by Sertoli cell cultures

As measured on day 3 of culture ( $48 \mathrm{~h}$ after the initial plating-down period), basal activin A levels in the culture medium were $45 \pm 19 \mathrm{pg} / \mathrm{ml}$ (mean \pm S.D.; $n=9$ cultures). It should be noted that even under the established culture conditions, basal activin A showed considerable variation from culture to culture (range: $<10-68 \mathrm{pg} / \mathrm{ml}$ ). Both IL- $1 \alpha$ and IL- $1 \beta$ stimulated the release of activin A from immature Sertoli cells by approximately 10-fold in a dose-dependent manner over an effective range of 5-20 U IL $-1 / \mathrm{ml}$ (Fig. 2A). The specificity of this response was indicated by the observation that total ir-inhibin release, as an indicator of $\alpha$-subunit protein secretion, was not significantly affected over the same range of doses (Fig. 2B). The corresponding intracellular content of activin A on day 3 was $7 \cdot 9 \pm 3 \cdot 3 \mathrm{pg} / 10^{6}$ cells (mean \pm S.D.; $n=3$ cultures) under basal conditions, and this was increased only slightly to $11 \cdot 6 \pm 2 \cdot 1 \mathrm{pg} / 10^{6}$ cells by addition of IL-1. Culturing the cells at $32{ }^{\circ} \mathrm{C}$ instead of $37^{\circ} \mathrm{C}$ reduced IL-1-stimulated activin A levels by approximately $25 \%$ without affecting basal activin A release (data not shown). However, neither culturing the Sertoli cells on a laminincoated surface nor depletion of residual adherent germ cells by hypotonic treatment had any significant effect on basal or IL-1-stimulated activin A release (data not shown).

In contrast to IL-1, IL-6 at doses up to $50 \mathrm{ng} / \mathrm{ml}$ had no consistent effect on activin A release, alone or in the presence of either IL-1 isoform (data not shown). All subsequent studies used either the IL- $1 \alpha$ or the IL-1 $\beta$ isoform, as indicated.

Regulation of activin $A$, inhibin $B$ and $m R N A$ for $\beta_{A}, \beta_{B}$ and $a$-subunits time-course studies

Under basal culture conditions, both activin A and inhibin $\mathrm{B}$ were progressively secreted into the culture medium over the initial $48 \mathrm{~h}$ of incubation, with detectable levels $(>10 \mathrm{pg} / \mathrm{ml})$ present by $8 \mathrm{~h}$ (Fig. $3 \mathrm{~A}$ and B). IL-1 $\alpha$ stimulated activin $A$ and suppressed inhibin $B$ secretion across this same time period. Stimulation of activin A by IL-1 was consistent with the effects seen at the mRNA level, with IL-1 $\alpha$ inducing maximal expression of $\beta_{\mathrm{A}^{-}}$ subunit mRNA around $8 \mathrm{~h}$ of culture (Fig. 3C). The dynamic effects of IL-1 on the inhibin B subunits were quite different, however, with progressive inhibition of the $\beta_{\mathrm{B}}$-subunit by IL- $1 \alpha$ across the entire 48 -h period (Fig. 3D). 

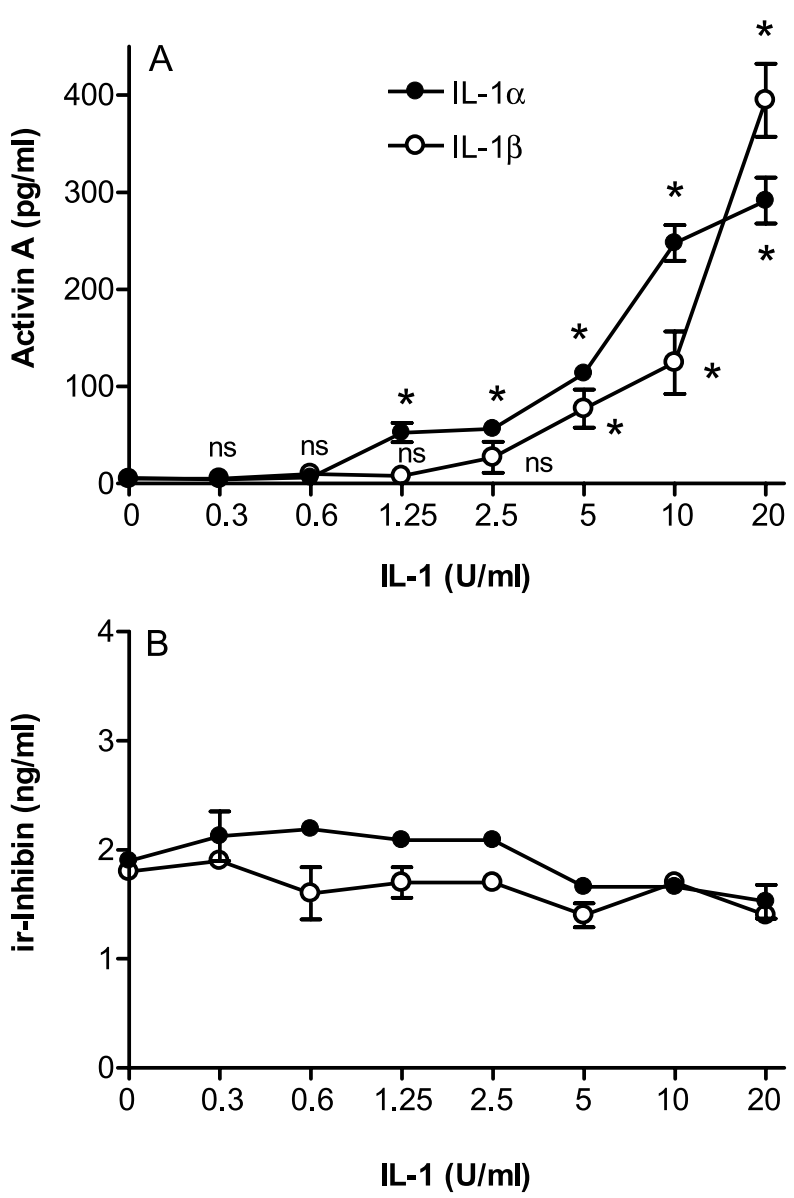

Figure 2 IL-1 $\alpha(-\bigcirc)$ and IL-1 $\beta(\bigcirc-\bigcirc)$ log dose-response curves for secretion of activin $A(A)$ and ir-inhibin (B) by immature rat Sertoli cells, collected on day 3 of culture (incubation time $48 \mathrm{~h}$ ). All values are mean \pm S.E.M.; $n=4$ wells. Asterisk indicates significantly different from control (in absence of IL-1) at $P<0 \cdot 05$. Ir-inhibin values are not significantly different from control at any IL-1 dose.

In contrast to the other subunits, inhibition of the $\alpha$-subunit was transient, and significant inhibition was observed only at the 24-h time point (Fig. 3E). This latter observation was consistent with the failure to detect significant inhibition of $\alpha$-subunit protein in $48-\mathrm{h}$ cultures by ir-inhibin assay (Fig. 2B).

Although the Sertoli cells showed a reduction in response to IL-1 at the longer culture periods (days 3 and 5), cells maintained basal activin $A$ release, and retained responsiveness to IL-1 for up to 7 days in culture (Fig. 4A). Cell numbers, as measured by DNA content, appeared to decline slightly between days 3 and 7 of culture, but IL-1 had no significant effect on this parameter (Fig. 4B). Intracellular activin A levels were unaffected by the presence of IL-1 over the entire 7 days of culture (data not shown).
Effects of testosterone, FSH and dbcAMP on activin $A$ production by Sertoli cell cultures

Testosterone (50 or $100 \mathrm{ng} / \mathrm{ml}$ ) had no effect on basal or IL-1-stimulated activin A release by Sertoli cells (data not shown). In contrast, activin A was significantly inhibited by ovine FSH $(500 \mathrm{ng} / \mathrm{ml}$ ) (Fig. 5A). Moreover, FSH consistently antagonised the action of IL-1 on the release of activin A. IL-1 $\beta$ significantly inhibited the release of dimeric inhibin $\mathrm{B}$ regardless of the presence or absence of FSH in the culture (Fig. 5B). Likewise, IL-1 $\beta$ inhibited dimeric inhibin A release by these cultures, although the levels of inhibin A were extremely low compared with either activin A or inhibin B (Fig. 5C). In direct contrast to its effects on inhibin $\mathrm{B}, \mathrm{FSH}$ on its own inhibited the release of inhibin $\mathrm{A}$, and when it was combined with IL-1 $\beta$, a further inhibition was observed.

Similar to the action of FSH, dbcAMP antagonised the effects of IL-1 $\beta$ on activin A release, although even very high doses of dbcAMP were unable to suppress activin A to basal levels in these cultures (Fig. 6). Moreover, in contrast to FSH, dbcAMP did not significantly affect basal activin A secretion.

\section{Comparison of Sertoli cell and peritubular cell responses to IL-1}

After the separation of these two cell types by Percoll density gradients, it was found that peritubular cells also respond to IL-1 $\beta$ by increasing release of activin A (Fig. 7). While the peritubular cells secreted less activin A under basal conditions than Sertoli cells, they produced between 2-3 times more on a per cell basis after IL-1 stimulation. However, since peritubular cells comprised less than 10\% of the total cells in the Sertoli cell cultures, their in vitro contribution would be relatively minor overall.

\section{Discussion}

The availability of specific, two-site ELISAs that can discriminate between the inhibin A, inhibin B and activin A dimers has relatively recently enabled the measurement of the production of these proteins by testicular cells (Depuydt et al. 1999, Clifton et al. 2002). Earlier studies employed radioimmunoassays that did not readily discriminate between the inhibin/activin dimers and monomeric $\alpha$-subunit or $\beta$-subunit proteins, relied on extrapolation from mRNA data, or used semiquantitative approaches such as Western blot analysis to assess production of dimeric inhibin and activin by testicular cells (Toebosch et al. 1988, Risbridger et al. 1989, Kaipia et al. 1992, Klaij et al. 1992, Simpson et al. 1992, de Winter et al. 1993, 1994). Using these dimeric immunoassays, we have established that both Sertoli cells and peritubular cells from immature rat testes produce physiologically 

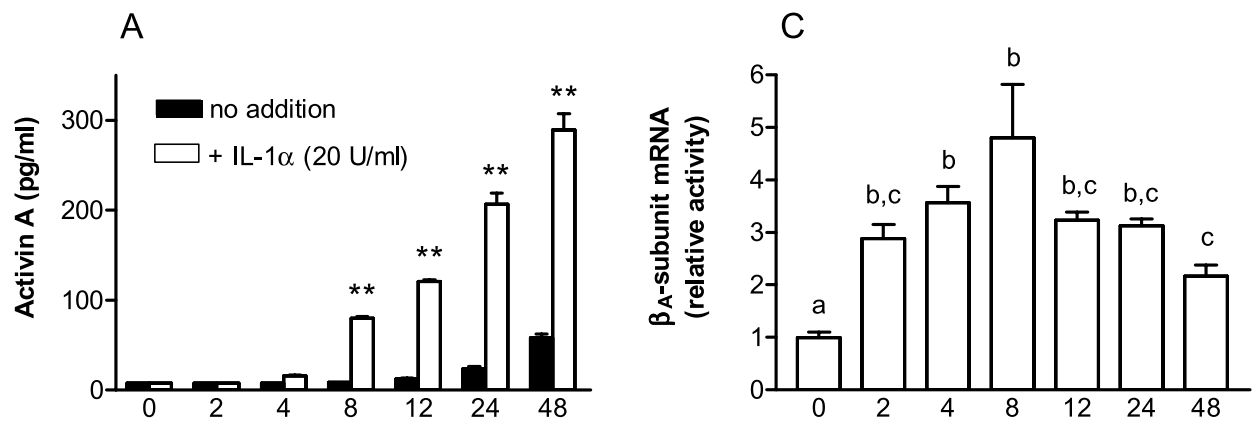

B
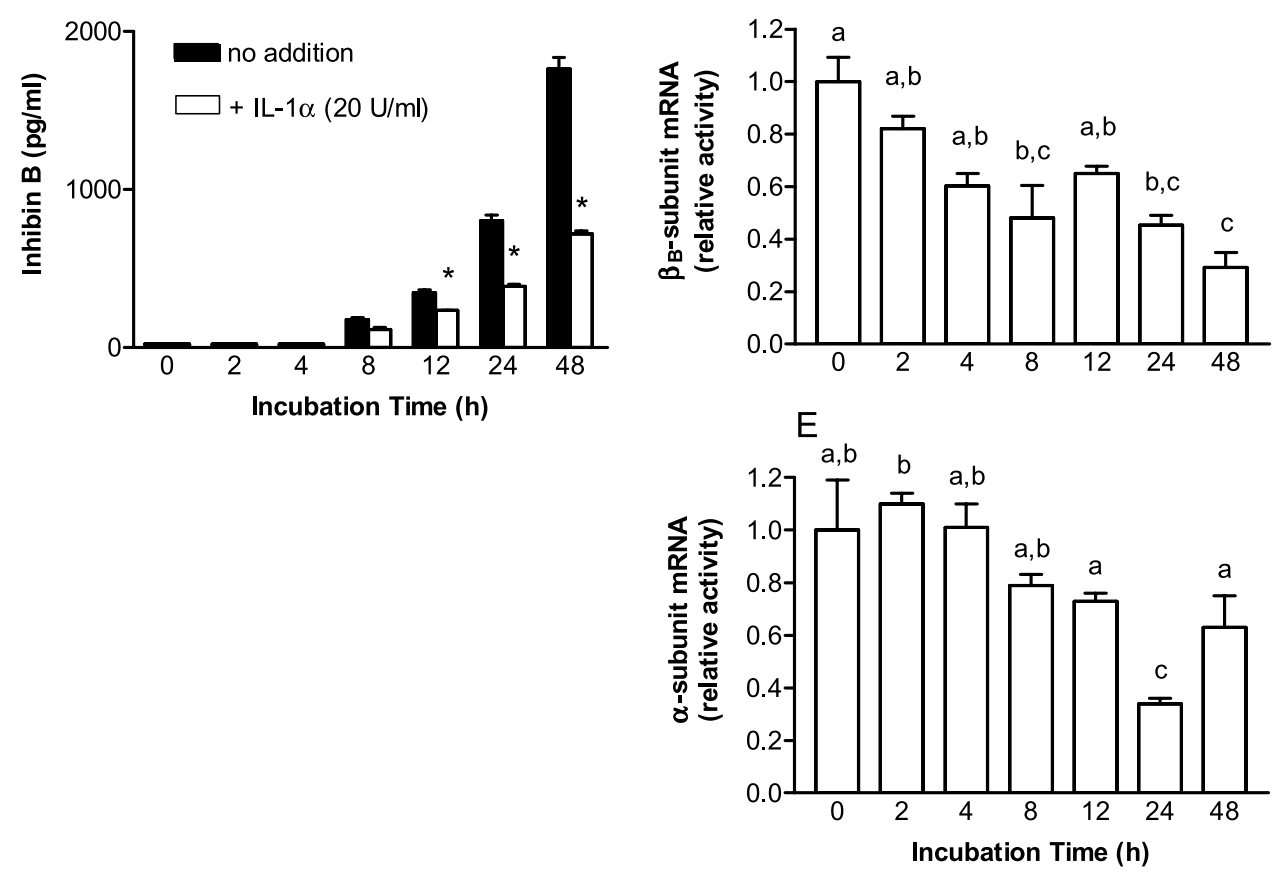

Figure 3 Time course $(0-48 \mathrm{~h})$ of secretion of $(A)$ activin $A$ and $(B)$ inhibin $B$, and expression of mRNA for $\beta_{A}$-subunit (C), $\beta_{B}$-subunit (D) and $\alpha$-subunit (E) in cultured immature rat Sertoli cells, in the presence of $20 \mathrm{U} / \mathrm{ml} \mathrm{IL-1} \alpha$ (open histograms) or in the absence of any addition (solid histograms). All values are mean \pm S.E.M.; $n=4$ wells. Statistical comparisons (panels A and B) are between basal and IL-1-stimulated secretion levels: ${ }^{*} P<0 \cdot 05$; ${ }^{*} P<0 \cdot 01$ (all other comparisons were not significant at $P<0 \cdot 05$ ). Values with same superscript letter (panels $C-E$ ) are not significantly different at $P<0 \cdot 05$.

significant amounts of dimeric activin $\mathrm{A}$ in vitro, and that IL-1, but not IL-6, is a specific stimulator of activin A synthesis by these cells. Studies in a number of other tissues have reported a stimulatory effect of IL-1 on activin production, which appears to involve IL-1-responsive promoter elements in the $\beta_{\mathrm{A}}$-subunit regulatory region (Tanimoto et al. 1996, Ardekani et al. 1998). In opposition to the action of IL-1, FSH inhibits basal activin A production by the Sertoli cell, and both FSH and cAMP inhibit IL-1-stimulated activin A secretion. These observations, together with the fact that IL-1 also inhibits both basal and FSH-stimulated inhibin B production, indicate for the first time the existence of a mechanism of reciprocal formation of activin A and inhibin B in the Sertoli cell regulated by IL-1 and FSH.

For measurement of the proteins in culture medium containing bicarbonate buffer, the assays were optimised and validated. A similar problem had been reported previously for the inhibin B ELISA (Clifton et al. 2002). Failure to account for $\mathrm{pH}$ variations in samples can lead to significant over- or underestimation of these molecules. According to the data from the modified ELISA, the amount of activin A produced after IL-1 stimulation is physiologically significant (i.e. in the high pg range). Consistent with other studies (Illingworth et al. 1996, Depuydt et al. 1999), secretion of inhibin A by Sertoli cells 

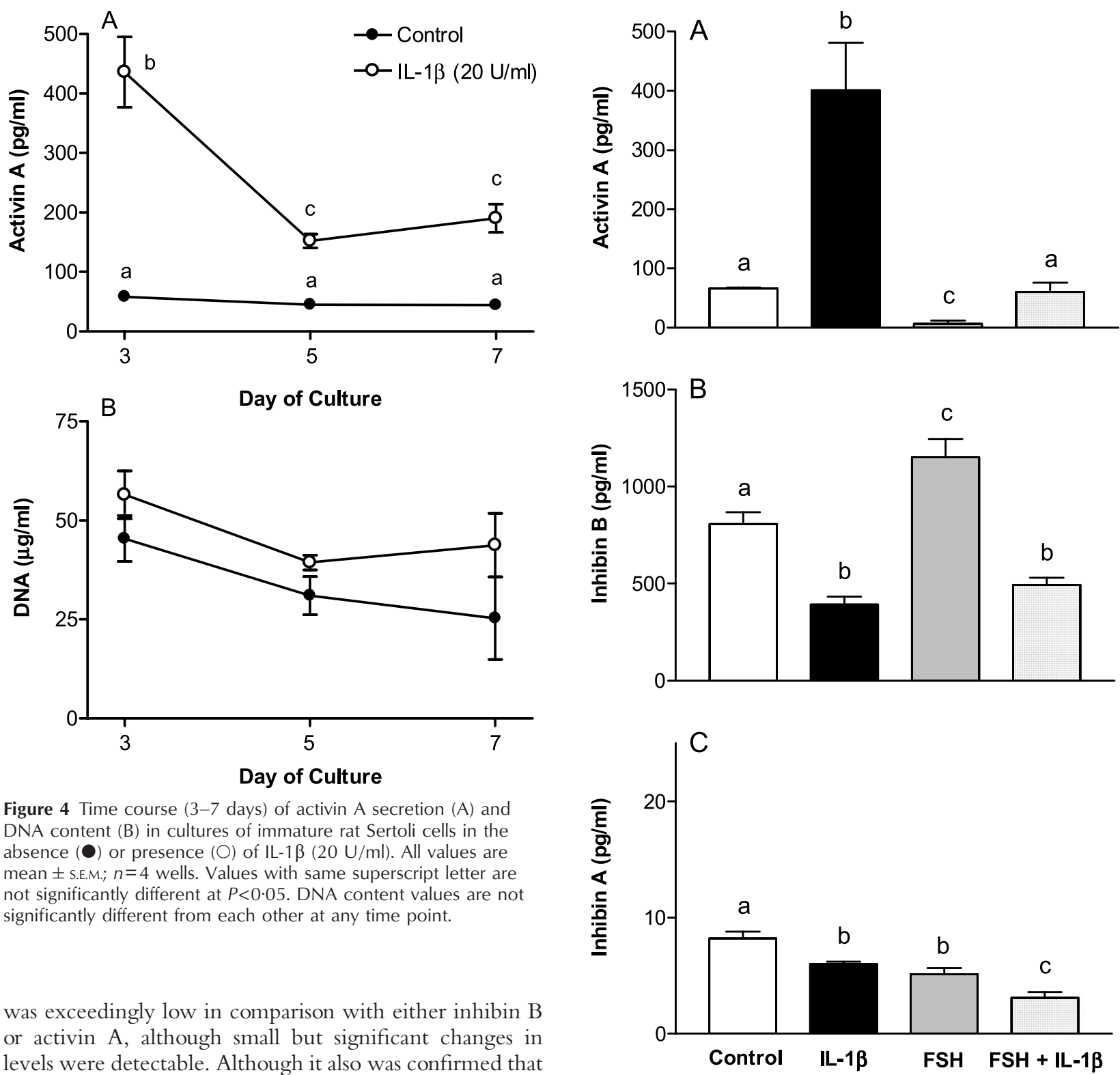

Figure 4 Time course (3-7 days) of activin A secretion (A) and DNA content $(B)$ in cultures of immature rat Sertoli cells in the absence $(\bullet)$ or presence $(O)$ of IL-1 $\beta(20 \mathrm{U} / \mathrm{ml})$. All values are mean \pm S.E.M.; $n=4$ wells. Values with same superscript letter are not significantly different at $P<0 \cdot 05$. DNA content values are not significantly different from each other at any time point.

was exceedingly low in comparison with either inhibin B or activin A, although small but significant changes in levels were detectable. Although it also was confirmed that peritubular cells produce activin A (de Winter et al. 1993, 1994) at levels comparable to those produced by Sertoli cells on a per cell basis, peritubular cells were only a minor cellular component of the cultures studied. In vivo, however, peritubular cells probably make a highly significant contribution to local activin A levels, as the number of these cells is approximately $25 \%$ of the total number of Sertoli cells (Ariyaratne \& Mendis-Handagama 2000). It is interesting that these cells were also stimulated by IL-1, and their role in the interaction between IL-1 and activin A warrants further exploration. Several culture variables also known to influence Sertoli cell responsiveness and/or inhibin/activin subunit expression were assessed: attachment to laminin (Dym et al. 1991), the presence of residual germ cells (Pineau et al. 1990, Clifton et al. 2002) and

Figure 5 Secretion of activin A (A), inhibin B (B), and inhibin A $(C)$ by immature rat Sertoli cells in the absence of cytokines (control), and in the presence of IL-1 $\beta(20 \mathrm{U} / \mathrm{ml})$, of FSH $(500 \mathrm{ng} / \mathrm{ml})$ or a combination of IL-1 $\beta$ and FSH, collected at day 3 of culture (incubation time: 48 h). All values are mean \pm S.E.M.; $n=4$ wells. Values with same superscript letter are not significantly different at $P<0 \cdot 05$.

incubation temperature (Gonzales et al. 1989). Only incubation temperature had any effect on activin A production in vitro.

The differential regulation of inhibin and activin within the testis through independent regulation of the subunits, which then associate intracellularly to form the relevant dimers, remains poorly understood. Early data suggested 


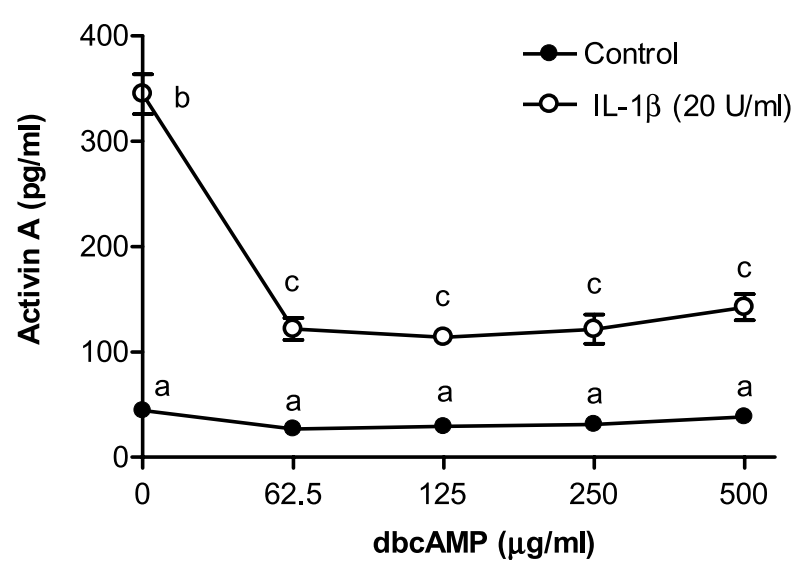

Figure 6 Dibutryl cAMP log dose-response curve for secretion of activin A by immature rat Sertoli cells, in the absence (-) or presence $(\bigcirc-\bigcirc)$ of IL-1 $\beta(20 \mathrm{U} / \mathrm{ml})$, collected on day 3 of culture (incubation time: $48 \mathrm{~h}$ ). All values are mean \pm S.E.M.; $n=4$ wells. Values with same superscript letter are not significantly different at $P<0 \cdot 05$.

that regulation of inhibin production by FSH in the Sertoli cell involved stimulation of the $\alpha$-subunit via a cAMPmediated pathway, with little or no apparent effect on either $\beta$-subunit (Toebosch et al. 1988, Klaij et al. 1992). More recent studies employing assays for the inhibin B dimer have led to a reassessment of this concept (Depuydt et al. 1999), with recognition that $\beta_{\mathrm{B}}$ mRNA expression in the Sertoli cell may be stimulated by cAMP analogues (Najmabadi et al. 1993, Depuydt et al. 1999). The data in the present study clearly indicate that FSH inhibits formation of both of the $\beta_{\mathrm{A}}$-subunit-containing dimers (activin A and inhibin A) in the Sertoli cell. This is quite different from the situation in the ovary, where FSH and
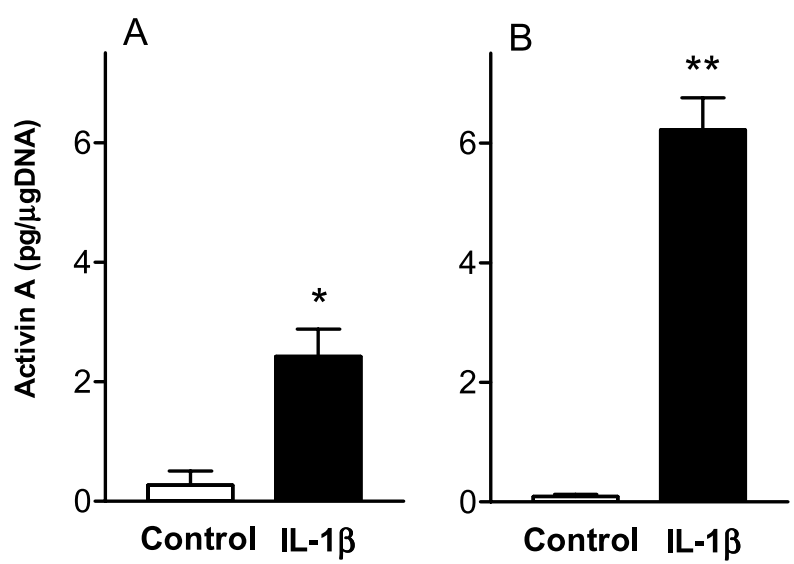

Figure 7 Comparison of activin A secretion, normalised against DNA content by Sertoli cells (A) or peritubular cells (B) separated by Percoll density gradient, in the absence (control) or presence of IL-1 $\beta(20 \mathrm{U} / \mathrm{ml})$, collected on day 3 of culture (incubation time: 48 h). All values are mean \pm S.E.M.; $n=4$ wells. Values are significantly different from control at ${ }^{*} P<0 \cdot 05$ or ${ }^{*} P<0 \cdot 01$.
cAMP stimulate inhibin A formation (Tuuri et al. 1996, Drummond et al. 2000). It is equally interesting that, even though IL-1 stimulates $\beta_{\mathrm{A}}$-subunit expression by the Sertoli cell, this does not result in an increase in inhibin A. It appears that most of the available $\beta_{\mathrm{A}}$-subunit produced in the Sertoli cell is preferentially directed to form the activin A homodimer. On the other hand, IL-1 inhibited secretion of the inhibin B dimer, primarily by inhibition of synthesis of the $\beta_{\mathrm{B}}$-subunit. This was quite different from the stimulatory effect of IL-1 on $\beta_{\mathrm{B}}$-subunit expression in the pituitary (Bilezikjian et al. 1998), although it should be noted that $\beta A$, and therefore activin $A$, is not normally expressed in the pituitary (Meunier et al. 1988, Schneider et al. 2000). Overall, it appears that the regulation of the activin/inhibin subunits and formation of the mature dimeric proteins in the Sertoli cell may be specific to this cell type.

In an earlier study, Khan and Nieschlag (1991) demonstrated that IL-1 $\beta$ can block FSH-stimulated, but not basal or dbcAMP-stimulated, aromatase activity in immature rat Sertoli cells, suggesting a site of action prior to the formation of cAMP. In the present study, IL-1 stimulated activin A production even in the presence of a saturating dose of dibutyryl cAMP, suggesting a site of action after cAMP formation. These data suggest that IL-1 can act both before and after cAMP formation in the Sertoli cell. A similar situation has been observed in rat Leydig cells, where IL-1 has been shown to have an inhibitory effect upon both LH/ human chorionic gonadotrophin-induced cAMP production and cAMP-stimulated testosterone production (Moore \& Moger 1991). A variable in the present studies was the wide variation in basal activin A production by the cultured Sertoli cells. The reasons for this variability are not clear, but endogenous IL- $1 \alpha$ production by the Sertoli cells is one likely explanation. Consequently, it was curious that FSH itself was able to inhibit basal activin A secretion, whereas dbcAMP had no effect, suggesting that the inhibitory effect of FSH on activin A may involve both cAMP-dependent and cAMPindependent pathways.

Regardless of the pathways involved, there is no doubt that FSH and IL-1 act through separate signalling pathways in the Sertoli cell. The fact that the IL-1 signalling pathway in the Sertoli cell does not involve the cAMP pathway through which FSH acts is entirely consistent with results in other tissues where cAMP is generally not involved in IL-1 signalling (Dinarello 1996). Recent reports of the involvement of the phospholipase A/ceramide pathway, a common regulatory pathway for IL-1 in other cells, in regulation of Sertoli cell function suggests that this pathway might be involved (Meroni et al. 1999). However, while they may act through separate pathways, the effects of IL-1 and FSH on the Sertoli cell are not uniformly antagonistic. Recent studies by Huleihel and colleagues (Huleihel \& Lunenfeld 2002, Huleihel et al. 2002) have shown that the effects of IL-1 and FSH on 
transferrin secretion by immature mouse Sertoli cells are additive.

The data in the present study further implicate activin A as a locally regulated cytokine within the testis, driven by IL-1 and suppressed by FSH. As a result, one potential role for activin A could be as a negative feedback inhibitor of IL-1 and IL-6 production and action within both the seminiferous tubules and interstitial tissue. Although there is no doubt that spermatogenesis can persist in mice deficient in IL-1, activin A, or even FSH production and/or signalling, albeit at a reduced level in some cases (Cohen \& Pollard 1998, Chang et al. 2001, Sairam \& Krishnamurthy 2001), the presence of these hormones/ cytokines and the intersection of their signalling pathways in this tissue must have physiological consequences. In this regard, it is interesting to note that there is cyclical regulation of both IL- $1 \alpha$ and $\beta_{\mathrm{A}}$-subunit mRNA across the cycle of seminiferous epithelium (Söder et al. 1991, Kaipia et al. 1992). These observations suggest that IL-1a and FSH may be involved in the regulation of activin A during the seminiferous cycle, with activin A potentially acting as a cyclical negative feedback regulator of local IL-1 and IL-6 action within the seminiferous epithelium. Recent data have confirmed that inhibin B is also regulated by specific germ-cell stages (Clifton et al. 2002), and it is reasonable to suggest that local production of IL-1 $1 \alpha$ may be involved in cyclical regulation of inhibin B as well. Finally, considerable evidence indicates that both inflammatory and immune responses in the testis are inhibited (Hedger 1997). The local production of activin A in response to the upregulation of IL-1 and IL-6 during a local inflammatory episode in the testis may be an important restraint upon the inflammatory response in the testis.

\section{Acknowledgements}

We are grateful to Sue Hayward and Julie Muir for their expert technical assistance. This work was supported by grants from the National Health and Medical Research Council of Australia (grant nos. 973218 and 143781). The authors declare that there is no conflict of interest that would prejudice the impartiality of this scientific work.

\section{References}

Abe M, Shintani Y, Eto Y, Harada K, Fujinaka Y, Kosaka M \& Matsumoto T 2001 Interleukin-1 $\beta$ enhances and interferon-gamma suppresses activin A actions by reciprocally regulating activin A and follistatin secretion from bone marrow stromal fibroblasts. Clinical and Experimental Immunology 126 64-68.

Ardekani AM, Romanelli JC \& Mayo KE 1998 Structure of the rat inhibin and activin $\beta_{\mathrm{A}^{-}}$subunit gene and regulation in an ovarian granulosa cell line. Endocrinology 139 3271-3279.

Ariyaratne HB \& Mendis-Handagama CS 2000 Changes in the testis interstitium of Sprague Dawley rats from birth to sexual maturity. Biology of Reproduction 62 680-690.
Bilezikjian LM, Turnbull AV, Corrigan AZ, Blount AL, Rivier CL \& Vale WW 1998 Interleukin-1 $\beta$ regulates pituitary follistatin and inhibin/activin $\beta_{\mathrm{B}}$ mRNA levels and attenuates FSH secretion in response to activin-A. Endocrinology 139 3361-3364.

Boitani C, Stefanini M, Fragale A \& Morena AR 1995 Activin stimulates Sertoli cell proliferation in a defined period of rat testis development. Endocrinology 136 5438-5444.

Boockfor FR \& Schwarz LK 1991 Effects of interleukin-6, interleukin-2, and tumor necrosis factor alpha on transferrin release from Sertoli cells in culture. Endocrinology 129 256-262.

Chang H, Lau AL \& Matzuk MM 2001 Studying TGF- $\beta$ superfamily signaling by knockouts and knockins. Molecular and Cellular Endocrinology 180 39-46.

Chapin RE, Phelps JL, Miller BE \& Gray TJ 1987 Alkaline phosphatase histochemistry discriminates peritubular cells in primary rat testicular cell culture. Journal of Andrology 8 155-161.

Chomczynski P \& Sacchi N 1987 Single-step method of RNA isolation by acid guanidinium thiocyanate-phenol-chloroform extraction. Analytical Biochemistry 162 156-159.

Clifton RJ, O’Donnell L \& Robertson DM 2002 Pachytene spermatocytes in co-culture inhibit rat Sertoli cell synthesis of inhibin beta B-subunit and inhibin B but not the inhibin alpha-subunit. Journal of Endocrinology 172 565-574.

Cohen PE \& Pollard JW 1998 Normal sexual function in male mice lacking a functional type I interleukin-1 (IL-1) receptor. Endocrinology 139 815-818.

Cudicini C, Lejeune H, Gomez E, Bosmans E, Ballet F, Saez J \& Jégou B 1997 Human Leydig cells and Sertoli cells are producers of interleukins-1 and -6. Journal of Clinical Endocrinology and Metabolism 82 1426-1433.

Depuydt CE, Mahmoud AM, Dhooge WS, Schoonjans FA \& Comhaire FH 1999 Hormonal regulation of inhibin B secretion by immature rat sertoli cells in vitro: possible use as a bioassay for estrogen detection. Journal of Andrology 20 54-62.

Dinarello CA 1996 Biologic basis for interleukin-1 in disease. Blood 87 2095-2147.

Drummond AE, Dyson M, Thean E, Groome NP, Robertson DM \& Findlay JK 2000 Temporal and hormonal regulation of inhibin protein and subunit mRNA expression by post - natal and immature rat ovaries. Journal of Endocrinology 166 339-354.

Dym M, Lamsam-Casalotti S, Jia MC, Kleinman HK \& Papadopoulos V 1991 Basement membrane increases G-protein levels and follicle-stimulating hormone responsiveness of Sertoli cell adenyly cyclase activity. Endocrinology 128 1167-1176.

Gérard N, Syed V, Bardin W, Genetet N \& Jégou B 1991 Sertoli cells are the site of interleukin-1 $\alpha$ synthesis in rat testis. Molecular and Cellular Endocrinology 82 R13-16.

Gérard N, Syed V \& Jégou B 1992 Lipopolysaccharide, latex beads and residual bodies are potent activators of Sertoli cell interleukin-1 $\alpha$ production. Biochemical and Biophysical Research Communications 185 154-161.

Gonzales GF, Risbridger GP \& de Krester DM 1989 In vivo and in vitro production of inhibin by cryptorchid testes from adult rats. Endocrinology 124 1661-1668.

Groome NP, Illingworth PJ, O'Brien M, Cooke I, Ganesan TS, Baird DT \& McNeilly AS 1994 Detection of dimeric inhibin throughout the human menstrual cycle by two-site enzyme immunoassay. Clinical Endocrinology 40 717-723.

Groome NP, Illingworth PJ, O'Brien M, Pai R, Rodger FE, Mather JP \& McNeilly AS 1996 Measurement of dimeric inhibin B throughout the human menstrual cycle. Journal of Clinical Endocrinology and Metabolism 81 1401-1405.

Groome NP, Tsigou A, Cranfield M, Knight PG \& Robertson DM 2001 Enzyme immunoassays for inhibins, activins and follistatins. Molecular and Cellular Endocrinology 180 73-77.

Hakovirta H, Kaipia A, Söder O \& Parvinen M 1993 Effects of activin- $\mathrm{A}$, inhibin- $\mathrm{A}$, and transforming growth factor- $\beta 1$ on 
stage-specific deoxyribonucleic acid synthesis during rat seminiferous epithelial cycle. Endocrinology 133 1664-1668.

Hakovirta H, Syed V, Jégou B \& Parvinen M 1995 Function of interleukin-6 as an inhibitor of meiotic DNA synthesis in the rat seminiferous epithelium. Molecular and Cellular Endocrinology 108 193-198.

Hales DB, Xiong Y \& Tur-Kaspa I 1992 The role of cytokines in the regulation of Leydig cell P450c17 gene expression. Journal of Steroid Biochemistry and Molecular Biology 43 907-914.

Hedger MP 1997 Testicular leukocytes: what are they doing? Reviews of Reproduction 2 38-47.

Hoeben E, Wuyts A, Proost P, Van Damme J \& Verhoeven G 1997 Identification of IL-6 as one of the important cytokines responsible for the ability of mononuclear cells to stimulate Sertoli cell functions. Molecular and Cellular Endocrinology 132 149-160.

Huleihel M \& Lunenfeld E 2002 Involvement of intratesticular IL-1 system in the regulation of Sertoli cell functions. Molecular and Cellular Endocrinology 187 125-132.

Huleihel M, Zeyse D, Lunenfeld E, Zeyse M \& Mazor M 2002 Induction of transferrin secretion in murine Sertoli cells by FSH and IL-1: the possibility of different mechanism(s) of regulation. American Journal of Reproductive Immunology 47 112-117.

Illingworth PJ, Groome NP, Byrd W, Rainey WE, McNeilly AS, Mather JP \& Bremner WJ 1996 Inhibin-B: a likely candidate for the physiologically important form of inhibin in men. Journal of Clinical Endocrinology and Metabolism 81 1321-1325.

Jégou B, Cudicini C, Gomez E \& Stéphan JP 1995 Interleukin-1, interleukin-6 and the germ cell-Sertoli cell cross-talk. Reproduction, Fertility, and Development 7 723-730.

Jonsson CK, Setchell BP, Martinelle N, Svechnikov K \& Söder O 2001 Endotoxin-induced interleukin 1 expression in testicular macrophages is accompanied by downregulation of the constitutive expression in Sertoli cells. Cytokine 14 283-288.

Kaipia A, Penttila TL, Shimasaki S, Ling N, Parvinen M \& Toppari J 1992 Expression of inhibin $\beta_{\mathrm{A}}$ and $\beta_{\mathrm{B}}$, follistatin and activin-A receptor messenger ribonucleic acids in the rat seminiferous epithelium. Endocrinology 131 2703-2710.

Keelan JA, Groome NP \& Mitchell MD 1998 Regulation of activin-A production by human amnion, decidua and placenta in vitro by pro-inflammatory cytokines. Placenta 19 429-434.

Khan SA \& Nieschlag E 1991 Interleukin-1 inhibits follitropininduced aromatase activity in immature rat Sertoli cells in vitro. Molecular and Cellular Endocrinology 75 1-7.

Klaij IA, Timmerman MA, Blok LJ, Grootegoed JA \& de Jong FH 1992 Regulation of inhibin $\beta_{\mathrm{B}}$-subunit mRNA expression in rat Sertoli cells: consequences for the production of bioactive and immunoreactive inhibin. Molecular and Cellular Endocrinology 85 237-246.

Knight PG, Muttukrishna S \& Groome NP 1996 Development and application of a two-site enzyme immunoassay for the determination of 'total' activin-A concentrations in serum and follicular fluid. Journal of Endocrinology 148 267-279.

de Kretser DM, Buzzard JJ, Okuma Y, O'Connor AE, Hayashi T, Lin SY, Morrison JR, Loveland KL \& Hedger MP 2004 The role of activin, follistatin and inhibin in testicular physiology. Molecular and Cellular Endocrinology 225 57-64.

Lee W, Mason AJ, Schwall R, Szonyi E \& Mather JP 1989 Secretion of activin by interstitial cells in the testis. Science 243 396-398.

Mather JP, Attie KM, Woodruff TK, Rice GC \& Phillips DM 1990 Activin stimulates spermatogonial proliferation in germ-Sertoli cell cocultures from immature rat testis. Endocrinology 127 3206-3214.

Means AR, MacDougall E, Soderling TR \& Corbin JD 1974 Testicular adenosine $3^{\prime}, 5^{\prime}$-monophosphate-dependent protein kinase. Regulation by follicle-stimulating hormone. Journal of Biological Chemistry 249 1231-1238.

Meehan T, Schlatt S, O’Bryan MK, de Kretser DM \& Loveland KL 2000 Regulation of germ cell and Sertoli cell development by activin, follistatin, and FSH. Developmental Biology 220 225-237.
Meroni SB, Cánepa DF, Pellizzari EH, Schteingart HF \& Cigorraga SB 1999 Effect of $N$ acetylsphingosine (C2) and the ceramidase inhibitor (1S,2R)-D-erythro-2-(N-myristoylamino)-1-phenyl-1propanol on the regulation of Sertoli cell function. Journal of Andrology 20 619-625.

Meunier H, Rivier C, Evans RM \& Vale W 1988 Gonadal and extragonadal expression of inhibin $\alpha, \beta_{\mathrm{A}}$, and $\beta_{\mathrm{B}}$ subunits in various tissues predicts diverse functions. PNAS 85 247-251.

Moore C \& Moger WH 1991 Interleukin-1 $\alpha$-induced changes in androgen and cyclic adenosine $3^{\prime}, 5^{\prime}$-monophosphate release in adult rat Leydig cells in culture. Journal of Endocrinology 129 381-390.

Najmabadi H, Rosenberg LA, Yuan QX, Reyaz G \& Bhasin S 1993 Transcriptional regulation of inhibin $\beta_{\mathrm{B}}$ messenger ribonucleic acid levels in TM. 4 or primary rat Sertoli cells by 8 -bromo-cyclic adenosine monophosphate. Molecular Endocrinology 7 561-569.

Nehar D, Mauduit C, Boussouar F \& Benahmed M 1998 Interleukin $1 \alpha$ stimulates lactate dehydrogenase A expression and lactate production in cultured porcine Sertoli cells. Biology of Reproduction 59 1425-1432.

O'Bryan MK, Schlatt S, Phillips DJ, de Kretser DM \& Hedger MP 2000 Bacterial lipopolysaccharide-induced inflammation compromises testicular function at multiple levels in vivo. Endocrinology $141238-246$.

Parvinen M, Söder O, Mali P, Fröysa B \& Ritzén EM 1991 In vitro stimulation of stage-specific deoxyribonucleic acid synthesis in rat seminiferous tubule segments by interleukin-1 $\alpha$. Endocrinology 129 1614-1620.

Petersen C, Boitani C, Fröysa B \& Söder O 2002 Interleukin-1 is a potent growth factor for immature rat sertoli cells. Molecular and Cellular Endocrinology 186 37-47.

Phillips DJ, Jones KL, Scheerlinck JY, Hedger MP \& de Kretser DM 2001 Evidence for activin A and follistatin involvement in the systemic inflammatory response. Molecular and Cellular Endocrinology $180155-162$.

Pineau C, Sharpe RM, Saunders PT, Gérard N \& Jégou B 1990 Regulation of Sertoli cell inhibin production and of inhibin $\alpha$-subunit mRNA levels by specific germ cell types. Molecular and Cellular Endocrinology 72 13-22.

Risbridger GP, Hancock A, Robertson DM, Hodgson Y \& de Kretser DM 1989 Follitropin (FSH) stimulation of inhibin biological and immunological activities by seminiferous tubules and Sertoli cell cultures from immature rats. Molecular and Cellular Endocrinology 67 $1-9$.

Robertson DM, Hayward S, Irby D, Jacobsen J, Clarke L, McLachlan RI \& de Kretser DM 1988 Radioimmunoassay of rat serum inhibin: changes after PMSG stimulation and gonadectomy. Molecular and Cellular Endocrinology 58 1-8.

Robertson DM, Foulds LM, Prisk M \& Hedger MP 1992 Inhibin/activin $\beta$-subunit monomer: isolation and characterization. Endocrinology 130 1680-1687.

Russell CE, Hedger MP, Brauman JN, de Kretser DM \& Phillips DJ 1999 Activin A regulates growth and acute phase proteins in the human liver cell line, HepG2. Molecular and Cellular Endocrinology 148 129-136.

Sairam MR \& Krishnamurthy H 2001 The role of follicle-stimulating hormone in spermatogenesis: lessons from knockout animal models. Archives of Medical Research 32 601-608.

Schneider O, Nau R \& Michel U 2000 Comparative analysis of follistatin-, activin beta A- and activin beta B-mRNA steady-state levels in diverse porcine tissues by multiplex S1 nuclease analysis. European Journal of Endocrinology 142 537-544.

Shao L, Frigon NL Jr, Sehy DW, Yu AL, Lofgren J, Schwall R \& Yu J 1992 Regulation of production of activin A in human marrow stromal cells and monocytes. Experimental Hematology 20 $1235-1242$. 
Simpson BJ, Hedger MP \& de Kretser DM 1992 Characterisation of adult Sertoli cell cultures from cryptorchid rats: inhibin secretion in response to follicle-stimulating hormone stimulation. Molecular and Cellular Endocrinology 87 167-177.

Söder O, Syed V, Callard GV, Toppari J, Pöllänen P, Parvinen M, Fröysa B \& Ritzén EM 1991 Production and secretion of an interleukin-1-like factor is stage-dependent and correlates with spermatogonial DNA synthesis in the rat seminiferous epithelium. International Journal of Andrology 14 223-231.

Syed V, Stéphan JP, Gérard N, Legrand A, Parvinen M, Bardin CW \& Jégou B 1995 Residual bodies activate Sertoli cell interleukin-1 $\alpha$ (IL-1 $\alpha)$ release, which triggers IL-6 production by an autocrine mechanism, through the lipoxygenase pathway. Endocrinology 136 3070-3078.

Tanimoto K, Yoshida E, Mita S, Nibu Y, Murakami K \& Fukamizu A 1996 Human activin $\beta_{\mathrm{A}}$ gene. Identification of novel 5' exon, functional promoter, and enhancers. Journal of Biological Chemistry $27132760-32769$.

Toebosch AM, Robertson DM, Trapman J, Klaassen P, de Paus RA, de Jong FH \& Grootegoed JA 1988 Effects of FSH and IGF-I on immature rat Sertoli cells: inhibin $\alpha$ - and $\beta$-subunit mRNA levels and inhibin secretion. Molecular and Cellular Endocrinology $\mathbf{5 5}$ 101-105.

Tuuri T, Erämaa M, Van Schaik RH \& Ritvos O 1996 Differential regulation of inhibin/activin $\alpha$ - and $\beta_{\mathrm{A}}$-subunit and follistin mRNAs by cyclic AMP and phorbol ester in cultured human granulosa-luteal cells. Molecular and Cellular Endocrinology 121 1-10.

de Winter JP, Vanderstichele HM, Timmerman MA, Blok LJ, Themmen AP \& de Jong FH 1993 Activin is produced by rat Sertoli cells in vitro and can act as an autocrine regulator of Sertoli cell function. Endocrinology 132 975-982.

de Winter JP, Vanderstichele HM, Verhoeven G, Timmerman MA, Wesseling JG \& de Jong FH 1994 Peritubular myoid cells from immature rat testes secrete activin-A and express activin receptor type II in vitro. Endocrinology 135 759-767.

Yu EW, Dolter KE, Shao LE \& Yu J 1998 Suppression of IL-6 biological activities by activin A and implications for inflammatory arthropathies. Clinical and Experimental Immunology 112 126-132.

Received in final form 22 December 2004 Accepted 18 January 2005 